\title{
Prospects of Oil Palm Wine and Raphia Palm Wine in South East, Nigeria
}

\author{
Nwankwo Temple Nneamaka \\ Department of Agricultural Economics and Extension, Nnamdi Azikiwe University, Awka Main Post Awka,
} Nigeria

\begin{abstract}
s
The study which compared the potentials of oil palm wine (OPW) and raphia palm wine (RPW) in South East, Nigeria was informed by the vast nutritional and economic values of the products, their potentials for poverty alleviation and dearth of information on the economics of marketing of the products in the area. The study specifically described the different ways in which oil palm wine and raphia palm wine can be utilized and also identified the differences and similarities in the utilization of both wines. The study population comprised all the oil palm wine and raphia palm wine consumers in South East, Nigeria. Purposive and random sampling techniques were used to select 150 respondents for the study. Primary data used for the study were analyzed using descriptive statistics. Palm wine has best potentials for use in refreshment, followed by ceremonies, traditional medicine, as raw materials, libation, lactation, and least weaning. Innovations such as use of hybrid plants, accurate plant spacing, new and efficient ways of tapping by associated Research Institutes in the country will help boost production.
\end{abstract}

Keywords: Oil palm wine, Prospects, Raphia palm wine

DOI: $10.7176 / \mathrm{JNSR} / 9-4-04$

\section{Introduction}

Human beings cannot survive without water for a long period of time, as normal functioning of the body requires a continual supply of fluid in various forms including beverages (Olufunke \& Oluremi, 2015). Beverages are food items that are consumed in liquid state, but have lower food values relative to milk, and milk products. They are consumed either for their thirst quenching properties or for their stimulating effects. Two categories may readily be recognized: non-alcoholic and alcoholic beverage drinks (Omotoso, Amao \& Oyeleye, 2014). Africans have been making and imbibing alcoholic beverages from a wide array of fruits, grains, and other natural substances for as far back as the historical record goes, and continue to do so, ranging from palm-wine in coastal West and East Africa, banana beer in the Great Lakes region, to mead (tejj) in Ethiopia, and maize/sorghum beer across Southern Africa. In Nigeria, various types of alcoholic beverages are consumed ranging from beer to wine and spirit categories. Some of the alcoholic beverages traditionally produced include burukutu, pito, ogogoro, and palm wine (Dimelu, Agbo \& Igbokwe, 2011). Palm wine is the collective name for a group of alcoholic beverages produced by the natural fermentation of the sap obtained from various tropical plants of the palmae family (Falegan \& Akoja, 2014). They further reported that indigenous people living in or close to swampy areas (such as the Ibos, Yoruba, Urhobos, Ijaws, and Itsekiris of Nigeria) prefer to tap their palm wine from raphia palm, while the Ibos prefer tapping their wine majorly from oil palm trees. The wine obtained from oil palm trees is called oil palm wine (OPW) while the palm wine obtained from raphia palm trees is called raphia palm wine (RPW) (Ikegwu, 2014). Fresh palm wine is sweet and contains little alcohol but, with fermentation, the alcohol content increases in time. Unbottled palm wine has a lower alcohol content (around 3\%) than bottled palm wine (around 4\%). A litter of palm wine contains approximately 300 calories, $0.5-2.0 \mathrm{~g}$ of proteins, considerable amount of vitamins, a major component of which is vitamin A which helps to protect and improve consumer's eye sight (Amanchukwu, Obafemi \& Okpokwasili, 2015). Raphia palm wine differs from oil palm wine in the following ways; it is sweeter and milkier, low alcohol level (intoxicating power), available all seasons and also relatively affordable (Aiyeloja et al. 2014). It is commonly thought to be a very nourishing drink which greatly promotes lactation, the root and wine are used in local medicines as prevention and therapeutics for malaria fever, stomach pain and related diseases (Aiyeloja et al. 2014). Sweet taste is solely responsible for the acceptability of raphia palm wine among the female gender, hence it is preferred to other local wines (Aiyeloja et al. 2014). On the contrary, the ability to intoxicate due to the alcohol level accumulated during fermentation on exposure to air is one of the factors that attracts young people to oil palm wine (Aiyeloja et al. 2014). Oil palm wine is also erroneously consumed as energy drink particularly among the farmers (operating on local cutlass and hoe for land tilling) and artisans that engage in other energy sapping activities. Palm wine is enjoyed at birth celebrations, funeral ceremonies, and plays an integral role during traditional marriage ceremonies (Mbuagbaw \& Noorduyn, 2012).

Recent literature search showed that despite the nutritional advantages of palm wine and its potential for poverty alleviation, relatively little research has been devoted to it. Most studies on palm wine concentrated on palm wine production, chemical compositions, nutritive values, preservation techniques of palm wine and health implications of palm wine consumption (Ezeronye \& Legras, 2009; Karamoko, Djeni, N'guessan, Bouatenin, \& 
Dje, 2012; Falegan and Akoja, 2014; Ikegwu, 2014; Ogueri, Ibekwe, Ekperechi, Udebuani, Nwanebu, Oguoma, \& Nnokwe, 2016). Consequently, the potentials of oil palm wine and raphia palm wine as important beverages and their associated nutritional and health advantages remain underexploited. Therefore the study compared the prospects of oil palm wine and raphia palm wine and specifically;

(i) described the different ways in which oil palm wine and raphia palm wine can be utilized; and

(ii) identified the differences and similarities in the utilization of both wines.

\section{Theoretical Framework}

\subsection{Theory of Consumer Behaviour}

The demand for palm wine is explained by consumer behavior theory. Consumer behavior theory is the study of what motivates consumers to demand a particular good or service. Consumer behavior studies individuals and groups when they select, purchase, use and dispose products, ideas, services or experience. It is much more than studying what consumers buy; it attempts to understand how the decision-making process goes and how it affects consumers' buying behavior (Madhavan \& Chandrasekar, 2015). Customer behavior study is based on consumer buying behavior, with the customer playing the three distinct roles of user, payer and buyer respectively. Marketers study consumers buying patterns to solve where they buy, what they buy and why they buy. However, why consumers buy a specific product is not easy to understand because the answer is locked deep within the consumers' mind.

Generally, consumers can be categorized into individual and organizational consumers. Individual consumers try to satisfy their own needs and wants by purchasing for themselves or satisfy the needs of others by buying for them. These individual consumers can come from different backgrounds, ages and life stages. Consumer choice and behaviour are complex concepts that are continuously studied by researchers. Meanwhile, it also helps them develop suitable marketing strategies to enhance profitability and sustain competitive advantage of their respective businesses

Consumers undergo a process to arrive at a final purchase decision. The study conducted by Madhavan \& Chandrasekar (2015) indicated that there are five stages of buying process: need recognition; information search; evaluation of alternatives; purchase decision and post purchase behaviour. The authors further added that the process is forward-moving that starts long hand before the purchase is made and continues even after the purchase is made. Kotler and Armstrong (2010) suggest that the consumer can skip a few stages during a routine purchase. However, when a consumer faces a new and complex purchase situation, all of these five stages need to be used to complete the buying process.

\section{Materials and Methods}

The study area is the Southeast geopolitical zone of Nigeria. The States in the South-east geopolitical zone are Abia, Anambra, Ebonyi, Enugu, and Imo, States. Southeastern Nigeria lies between latitude $40^{0} 50^{1} \mathrm{~N}$ to $70^{0} 10^{1} \mathrm{~N}$ and longitudes $60^{0} 40^{1} \mathrm{E}$ to $80^{0} 30^{1} \mathrm{E}$. The mean minimum and maximum temperatures range from $21^{0}-30^{\circ} \mathrm{C}$ in the coast to $29^{\circ} \mathrm{C}-33^{\circ} \mathrm{C}$ in the interior. The temperature is suitable for the growing of tree crops such as oil and raphia palms from which oil and raphia palm wines are respectively tapped and hence encourages the tapping and processing of palm wine from palm wine to distilled gin. The sap used to obtain palm wine is mostly taken from oil palm tree (Elaeis guineensis) and raphia palm tree (Raphia hookeri and Raphia vinifera). There are several species of both oil palm and Raphia palm but all are capable of producing wine. Palm wine tapping is a difficult task involving climbing or axe felling coupled with the difficult swampy terrain (especially for raphia palms), therefore men are solely engaged in wine tapping while mainly women and children undertake processing and marketing activities (Ikegwu, 2014).

The study population comprised all the oil palm wine and raphia palm wine consumers in South East, Nigeria. Purposive and random sampling techniques were used to select respondents for the study. Three states (Anambra, Imo and Enugu) were purposively selected from the five States in South East, Nigeria. The selection was based on the degree of concentration of palm wine production, processing and marketing activities in the area. Also, a random selection of five Local Government Areas (LGAs) from each State (15 LGAs), and one palm wine market from each of the selected LGAs (fifteen markets). Finally, five OPW and RPW consumers were selected from each of the markets to arrive at a sample size of 150 respondents.

Primary data were used for the study in which questionnaire were administered to the respondents by hand. The questionnaire captured data on the potentials of oil palm wine and raphia palm wine respectively.

A 4-point Likert type scale was deployed in determining the degree of importance to palm wine. The respondents were asked their perceived uses of palm wine, and the responses were ranked in a sort of dimension or disaggregated along a continuum. The response indicating the most valued usage was given the highest score. Response on the prospects of palm wine was disaggregated as follows:

Highly valuable $(\mathrm{HV}) \quad=4$

Valuable $(\mathrm{V}) \quad=3$ 
Moderately valuable (MV)

Not Valuable (NV)

Determination of cut-off point,

Cut off point $(x)=\sum \frac{f}{n}$

$$
=\frac{4+3+2+1}{4}=\frac{10}{4}=2.50
$$

To make inferential statement, the mean score were compared with the critical mean of 2.5. If the calculated mean of a problem is higher than the standard critical value, then, the potential is regarded as highly valued under each variable, the variable with mean score that ranges from $2.0-2.49$ as valuable, $1.5-1.9$ as moderately valuable, less than 1.5 as not valuable.

\section{Results and Discussion}

\subsection{Prospects of palm wine}

The utilization of any product depends on the purpose for which the good is used, on the income of the user, and the availability of the product. Market research was carried out in each of the already selected markets to identify the potentials of palm wine in order to have an insight of tapped and untapped potentials of the product. Table 1 presents ranking of potentials of palm wines in the area.

Table 1 Rankings of potential of the oil palm wine

\begin{tabular}{lccc} 
Uses & Mean & Rank & Decision \\
\hline Refreshment & 3.0 & $1^{\text {st }}$ & HV \\
Ceremonies & 2.9 & $2^{\text {nd }}$ & HV \\
Traditional medicine & 2.1 & $4^{\text {th }}$ & V \\
Raw materials & 1.9 & $5^{\text {th }}$ & MV \\
Libation & 1.8 & $6^{\text {th }}$ & MV \\
Lactation & 0.0 & $7^{\text {th }}$ & NV \\
Weaning & 2.5 & $3^{\text {rd }}$ & HV \\
\hline
\end{tabular}

Source: Field survey, 2017.

Refreshment was ranked $1^{\text {st }}$ for both OPW (3.0) and RPW (2.9). It is highly valuable because the mean score was above the cut-off point (2.5). Palm wine is drunk by both old and young people, it has no age or gender barrier; it is usually consumed for its thirst quenching and stimulating effects. This finding agrees with Aiyeloja et al. (2014) who reported that a higher number of people consume raphia palm wine as refreshment in Delta State. Aiyeloja et al. (2014) also noted that the female gender prefer the raphia palm wine to other local wines due to its sweet taste, while the men folk (especially young ones) prefer the oil palm wine due to its high ability to intoxicate. The use of palm wine during ceremonies ranked $2^{\text {nd }}$ with mean scores of 2.9 and 2.8 for OPW and RPW respectively. Palm wine is enjoyed at birth celebrations, funeral ceremonies and plays an integral role during traditional marriage ceremonies. In the study area, a bride confirms a bridegroom as her husband by pretending to seek him out among the crowd and kneeling down to symbolically present a calabash of palm wine to him.

This finding agrees with Mbuagbw \& Noorduyn (2012) who noted that palm wine is used during celebrations. Rich men and women who can afford to buy other types of expensive English wines and costly sports ensure that palm wine is in the exclusive list of drink to be provided at all their ceremonies.

Table 2. Rankings of potential of the raphia palm wine

\begin{tabular}{llll}
\hline \multicolumn{1}{c}{ Uses } & Mean & Rank & Decision \\
\hline Refreshment & 2.9 & $1^{\text {st }}$ & HV \\
Ceremonies & 2.8 & $2^{\text {nd }}$ & HV \\
Traditional medicine & 2.1 & $4^{\text {th }}$ & V \\
Raw materials & 1.8 & $5^{\text {th }}$ & MV \\
Libation & 1.7 & $6^{\text {th }}$ & MV \\
Lactation & 2.5 & $3^{\text {rd }}$ & HV \\
Weaning & 0.0 & $7^{\text {th }}$ & $\mathrm{NV}$ \\
\hline
\end{tabular}

Source: Field survey, 2017.

Further analysis of the result revealed that weaning was ranked $3^{\text {rd }}$ as a highly valued potential of OPW $(\mathrm{M}=2.5)$. This implies that OPW slows down the production of breast milk and can therefore be drunk by lactating mothers who want to wean their babies.

On the contrary, the finding indicated that lactation ranked $3^{\text {rd }}(M=2.5)$ among the potentials of RPW. This is basically attributed to the ability of raphia palm wine to boost breast milk production in lactating mothers. This finding agrees with Chandrasekhar, Sreevani, Seshapani,\& Pramodhakumari (2012) who reported that palm wine and its distillate are important solvent in herbal -medicinal administration , pregnant women consume it fresh for 
the sweetness and nutrition while nursing mothers drink it warm to enhance breast milk production. This finding is also in tandem with Aoyeloya et al. (2014) who reported that raphia palm wine is a nourishing drink which greatly promotes lactation. It also corroborates Mbuagbw \& Noorduyn (2012) that raphia palm wine promotes lactation.

It could be seen from the table that traditional medicine was ranked $4^{\text {th }}(\mathrm{M}=2.1)$ for both OPW and RPW, and it was a valuable potential in the area. The use of palm wine in traditional medicine could probably be related to the fact that palm wine is rich in calories, protons, vitamin A and other vitamins. This finding is in agreement with Aiyeloja et al. (2014) which reported that the root and wine are used in local medicines as prevention and therapeutics for malaria fever, stomach pain and related diseases.

The use of palm wine as raw materials as a moderately valuable potential was ranked $5^{\text {th }}(\mathrm{M}=1.9)$ and $(\mathrm{M}=1.8)$ for OPW and RPW respectively. Palm wine can be utilized as a raw materials from which other products can be gotten. Fermented palm wine can be used for distilling other stronger drinks such as burukutu, local gin and whiskey. Also, as acetification occurs after alcoholic fermentation of the wine it is used for making vinegar. This finding agrees with Amanchukwu et al. (2015) who indicated that palm wine can be used as a yeast substitute for leaving food products. It also agrees with Aiyeloja et al. (2014) who indicated that the sugar in palm wine can be used for making honey and jaggery.

The $6^{\text {th }}$ use of palm wine was libation $(\mathrm{M}=1.8)$ for OPW and $(\mathrm{M}-1.7)$ for RPW. Palm wine libation is a moderately important for sacrificial emblem to appease gods in the study area. This finding is in agreement with Etukudo (2003) who revealed the utilization of palm wine for cultural purposes in Ibibio tribes of Nigeria. Aiyeloja et al. (2014) also reported that palm wine is used for libation among the Yoruba tribes.

Finally the lactation was ranked $7^{\text {th }}(M=0.00)$ for OPW while weaning was ranked $7^{\text {th }}(M=0.00)$ for $R P W$ as not valued potentials.

\section{Conclusion}

Palm wine has best prospectus for use as refreshment, used during ceremonies, as raw materials, and for libation. The least prospect for OPW and RPW for use during weaning and lactation respectively. Palm wine is a special beverage due to the different roles it plays in different occasions and so should be accorded more research interests in order to promote its production and marketing at both local and international markets. Government should, therefore, increase budgetary allocation to research institutes such as NIFOR to encourage more researches on production, preservation and marketing of palm wine. The Government should create more palm wine bottling small scale industries or encourage the existing ones by providing equipments needed to bottle fresh wine and sell them at reasonable prices to individuals as well as organize workshops to educate them on the applications.

\section{REFERENCES}

Aiyeloja, A. T., Oladele, O., \& Tumulo, N. (2014), Potentials of Raphia hookeri Wine in Livelihood Sustenance among Rural and Urban Populations in Nigeria. International Journal of Social, Behavioral, Educational, Economic, Business and Industrial Engineering, 8(7): 2325-2332.

Amanchukwu, S.C., Obafemi, A., \& Okpokwasili, G. C. (2015), Hydrocarbon degradation and utilization by a palm-wine yeast isolate. FEMS Microbiolological Letter, (57):151-154. DOI: 10.1111/j.15746968.1989.tb03290.x.

SChandrasekhar, K., Sreevani, S., Seshapani, P. \& Pramodhakumari, J. (2012), International Journal of Research in Biological Sciences, 2 (1):33-38.

Dimelu, M. U., Agbo, C., \& Igbokwe, E. M. (2011), Pattern of alcohol consumption and its effects on livelihood in selected rural communities of Enugu state, Nigeria. Asian Journal of Agriculture and Rural Development, 1(2): 69-79.

Ezeronye, O.U., \& Legras, J. L. (2009), “Genetic analysis of Saccharomyces cerevisiae strains isolated from palm wine in eastern Nigeria: comparison with other African strains". Journal of Applied Microbiology, 10(6), 1569-1578.

Falegan, C. R. \& Akoja, S.O. (2014), "Microbiological and physicochemical studies of two Nigerian fermented alcoholic drinks (palmwine and burukutu) in Ekiti state, Nigeria". European Journal of Food Science and Technology, 2 (2), 13-22.

Ikegwu, J. U. (2014), "The value of palm wine tapping in the food production practices of Igbo-land: a case study of Idemili South Local Government Area, Anambra State". Journal of Research on Humanities and Social Sciences, 4(6), 49-54.

Karamoko, D., Djeni, N. T., N'guessan, K. F., Bouatenin, K. M. J. \& Dje, K. M. (2012), “The biochemical and microbiological quality of palm wine samples produced at different periods during tapping and changes which occurred during their storage". Food Control Journal, 26 (2), 504-511.

Madhavan, M., \& Chandrasekar, K. (2015), "Consumer buying behaviour: an overview of theory and models". Journal of Humanities and Social Sciences, 1(1), 74-112. 
Mbuagbaw, L. \& Noorduyn, S. G. (2012), "The palm wine trade: occupational and health hazards".

Ogueri, N., Ibekwe, V. I., Ekperechi S. A., Udebuani, A. C., Nwanebu, F C., Oguoma, O. I. \& Nnokwe, J. C. (2016), "Article evaluation of fermentation products of palm wine yeasts and role of Sacoglottis gabonensis supplement on products abundance". MDPI Journal, 2(9), 1-13.

Olufunke A. \& Oluremi K.O. (2015), "Assessment of Nutritional and Sensory Quality of Zaki - A Home-made Traditional Nigerian Beverage”. Journal of Nutrition and Food Sciences, 5(3), 5-8.

Omotoso, A.B., Amao, S.A. \& Oyeleye, I. (2014), "Consumption of non-alcoholic beverages in Egbeda local government area of Oyo State". Agriculture and Biology Journal of North America, 5(2), 78-86. 